\title{
Teungku Inong Dayah: Female Religious Leaders in Contemporary Aceh
}

\author{
Eka Srimulyani*
}

This chapter focuses on female ulama in Aceh, known locally as teungku inongs. ${ }^{1}$ I will concentrate in particular on teungku inongs of traditional Islamic educational institutions, known as dayah. In this chapter, I argue that, even though there are relatively few female ulama (as compared to their male counterparts), their roles as social agents and religious authorities are significant in the broader constellation of Islam in contemporary Aceh. Apart from being influential religious leaders within their local communities, some of these female ulama are also active in broader areas of social life. This chapter is based on several stories of teungku inongs from different areas in Aceh. The discussion of these figures will be organized around the major bases of their authority, either through their ties of kinship to a male religious figure or on the basis of their own personal and professional accomplishments. I will analyse these two ways of assuming authority in terms of 'ascribed power' and 'achieved power', respectively.

In Java, most nyais (wives or daughters of the pesantren leader, kiai) in traditional pesantrens have historically come from the immediate families of a kiai (see Srimulyani 2009) and have therefore assumed authority through the 'ascribed power' of kinship. However, according to my observations, the teungku inong dayahs in Aceh have more diverse ways of assuming authority and asserting agency. While some of these female religious leaders come from established families of dayah teachers, others have established themselves through the initiative of founding and leading their own dayah. ${ }^{2}$ The

* The data presented in this chapter were gathered during my postdoctoral research project that was funded by the Royal Academy of Arts and Sciences, The Netherlands (2010-2012). I would like to thank Sehat Ihsan Shadiqin for assisting me with the interviews and transcribing some interview data.

1 The word 'inong' in Acehnese means woman, or wife.

2 Comparable to the institution of pesantren in Java, the dayah constitutes the main model of traditional Islamic education in Aceh. I will use the term pesantren when referring to the national or Javanese context, while for Aceh I will use the term dayah. 
different ways in which these female ulama assume authority reveal significant aspects of the diverse processes informing the construction of female religious authority in the context of Acehnese Islam.

Although recent research has increasingly focused on the position of Muslim women in Indonesia, as yet little attention has been paid to the specific roles of female ulama. Traditional forms of Islamic historiography rarely deal with female religious leaders, and this general trend is also reflected in many works on Indonesian ulama (Azra 2002, xxi-xxxviii). In 2002, the Indonesian publisher Pustaka Gramedia Utama issued a book titled Ulama Perempuan Indonesia (Indonesian Female Ulama), which was edited by Jajat Burhanudin (Burhanudin 2002). The qualifications that the editor of this book used to select female ulama are, however, problematic and several female ulama, such as Nyai Khoiriyah, who should have been included, are not mentioned in the book (Srimulyani 2008, 126). ${ }^{3}$ Since 2004, The State Institute for Islamic Studies (IAIN, presently UIN) Ar-Raniry has published two volumes of the Ensiklopedi Pemikiran Ulama Aceh, but together they also contain entries for only two women. One of them was Tgk. Fakinah, ${ }^{4}$ who was a dayah leader herself and who is regarded as an Acehnese heroine, for her role in the armed struggle against the Dutch at the end of the nineteenth Aceh. However, the roles of other female ulama associated with dayahs in Aceh, such as Umi Rabi'ah from Dayah Darussalam Aceh Selatan, were left unrecognized in these volumes. Similarly, organizations of dayah ulama, such as Inshafuddin or HUDA (Himpunan Ulama Dayah Aceh), have very few female members, let alone women in leadership positions.

This chapter is based on field research I conducted in Aceh between 2010 and 2012. The teungku inongs discussed in this chapter come from different areas in Aceh and from different social backgrounds. Some of them are immediate family members of a dayah leader, whereas others are from non-day ah families. I conducted interviews with them in their hometowns, or when they visited

3 Nyai Khoiriyah is the daughter of Kiai Hasyim Asya'ary of Pesantren Tebu Ireng, Jombang (East Java). She lived for almost 20 years in Mecca from 1938-1957. In my interviews with some pesantren leaders (or kiai) in Jombang, including the late Kiai Yusuf Hasyim (Pak Ud) who was the leader of Pesantren Tebuireng, she was recognised as a learned ulama. She herself was a leader of Pesantren Seblak, and a member or Majelis Syuriah of the national organization Nahdlatul Ulama (PBNU).

4 Tengku Fakinah was both a heroine of anti-colonial resistance and an Islamic scholar. She had several female pupils, such as Teungku Fathimah Batee Linteung, Teungku Sa'idah Lamjame, Teungku Fathimah Ulee Tutue, and Teungku Hawa Lamdilip. See Mardhiah Aly (1980). 
Banda Aceh. By exploring their life stories, I aim to draw attention to the ways in which they established their authority. In the next section, I will explore the sociological and historical contexts of women in dayah education. This is followed by stories of some female dayah leaders from the field, and discussions of their agency and authority. The last part of the chapter focuses on their perception of women's issues, particularly within the context of Aceh's contemporary state Shari'a project.

\section{Female Ulama: Roles and Limits}

In Aceh, as well as at the Indonesian national level, women make up only a small minority of the official Ulama Council. At all levels, they are thus under-represented both in terms of the organization's leadership structure and in terms of its membership. There are only a handful of female members on the Council, most of whom have a university rather than a dayah background and work as lecturers at the IAIN. In the district of Aceh Besar two female ulama were involved in, and invited to, the activities of the District Ulama Council. Nevertheless, only one of them remains relatively active. Walidah Marhamah, from the dayah in Tanoh Meurah, has become a member of the Ulama Council in the district of Bireuen. Umi Hanisah from the district of Aceh Barat is another female ulama who has taken on a public role through membership in a formal ulama dayah organization, namely HUDA (Himpunan Ulama Dayah Aceh).

Yet, the positions of Walidah Marhamah and Umi Hanisah are exceptional compared with the positions of other teungku inongs with a day ah background. The exact number of female ulama active in formal Islamic organizations in Aceh, such as the Ulama Council (Majelis Permusyawaratan Ulama/MPU), Inshafuddin, HUDA, or MUNA (Majelis Ulama Nanggroe Aceh), ${ }^{5}$ is not clear. My personal estimation is that they make up less than 5 per cent of these organizations.

A number of teungku inong - both dayah leaders and those who run more simple schools known locally as balee semeubeut — prefer to stay outside these formal organizations and engage their respective communities more di-

5 The MPU is an official ulama organization. The rest are non-official; Inshafuddin is associated with traditionalist ulama, HUDA is the organization of ulama dayah, and MUNA was related to one particular local political party (Partai Aceh/PA) at the time of its establishment. 
rectly. ${ }^{6}$ There are only a few teungku inongs who are also leaders of dayah. Other teungku inongs, graduated from dayah, go on to establish balee seumeubeut where they teach the religious congregation, usually only women, on a regular basis. Some balee seumeubeut are also used by children who learn to recite the Quran or basic Islamic teachings. Some female students from Dayah Seulimeum in Aceh Besar whom I met and had a conversation with during my fieldwork, expressed their intention to establish a balee seumeubeut in their village upon their return from Dayah Seulimeum. Some of them had spent more than ten years in the dayah, and delivered sermons to some religious congregations around the dayah on a weekly basis. Furthermore, they also taught their juniors in the dayah.

The ulama have a long and rich history in Aceh, and their roles in relation to state power have been particularly complex since the twentieth century (Feener, this volume). In 1953, a group of modernist ulama began an armed insurgency against the political centre in Jakarta, which is generally referred to as the Darul Islam (DI) rebellion. The initial DI movement originated from West Java with the proclamation of an Indonesian Islamic State by DI's founding father, Kartosuwiryo. During the 1950s, other regional movements for the establishment of an Islamic state in Sulawesi, Kalimantan and Aceh were associated with the Darul Islam (Formichi 2012). The DI movement in Aceh was led by a former Governor of Aceh, who was also an ulama, Abu Daud Beureueh. He was the leader of the modernist organization PUSA (Persatuan Ulama Seluruh Aceh, All-Acehnese Association of Ulama). The Di movement in Aceh was one of the most serious armed conflicts in Indonesia in the post-independence years.

During Suharto's New Order regime (1965-1998), the ulama and their organizations were to some extent 'politicized' or involved in the state or the government's (political) development programs (see Feener, this volume). The official state ulama organization was established in 1965. It was originally known as MUDA (Majelis Ulama Daerah Aceh), which was later changed into MUI (Majelis Ulama Indonesia), and then MPU (Majelis Permusyawaratan Ulama). The provincial MPU organization has four women in its structure of $45 \mathrm{mem}$ bers. At the time of my research, all of those MPU women members had university backgrounds and tended toward more 'modernist' religious orientations, rather than coming out of Aceh's traditional dayah.

Outside these state and official organizations, most of the dayah-affiliated ulama in Aceh are members of dayah-based ulama organizations, such as

6 Balee semeubeut is a simple and humble place for learning. Usually it is a semi-permanent building made from wooden materials. 
PERTI (Persatuan Tarbiyah Islamiyah) and Inshafuddin. Since the end of the New Order regime, new organizations have also emerged, including HUDA and MUNA. Some Acehnese ulama such as Teungku Faisal Ali, the leader of Dayah Mahyal Ulum, are also members or leaders of the national organization of ulama called NU (Nahdlatul Ulama). Junior ulama dayahs have a separate organization called Rabithah Thalibah Aceh (RTA). None of these organizations have many female members, and they rarely engage with programs or activities that deal with women's issues. Only the RTA, through its Muslimat division, has played a visibly active role in promoting gender equity or equality in dayah life and in arguing against gender-based violence. RTA took on this role especially in the post-tsunami and post-conflict years, when many donors and agencies looked for local organizations to function as partners. During those years, RTA worked with organizations such as The Asia Foundation, which supported their programs through trainings, workshops and other activities. The Asia Foundation engaged dayahs and dayah people in their programs, particularly addressing the younger generation that was familiar with foreign institutions and organizations as well as with the wider gender discourse.

The state implementation of Islamic law in twenty-first century Aceh has affected various dimensions of socio-religious life in Aceh. In the educational sector for instance, the provincial policy of 'pendidikan Islami' (Islamic education) was introduced in 2008 through a local regulation (qanun) on education in Aceh. This means that more emphasis has been given to Islamic education, even in the 'general' or 'secular' school curricula. State Shari'a legislation has also placed more restrictions on the relationship between men and women through, for example, legislation on khalwat (illicit proximity of marriagable men and women) and through the implementation of formal regulations on Islamic dress. To some extent, female religious congregations even seem to have replaced other gatherings for women such as the Pembinaan Kesejahteraan Keluarga (PKK/Women's Welfare Movement).

After the 2004 tsunami and the 2005 peace agreement that put an end to decades of armed conflict between the central Indonesian government and the Free Aceh Movement (Gerakan Aceh Merdeka/GAM), Aceh experienced another set of remarkable socio-political changes. One of the most important developments is that the political role of the ulama has increased as their formal structure became one of the main pillars of Acehnese autonomy (as mentioned in Undang-Undang No. 11, 2006). It is against this background, then, that this chapter looks at the agency of female ulama in Aceh. It will examine the roots and modes of their agency and their authority as religious scholars. 


\section{Women and Traditional Islamic Learning in Acehnese Society}

This section explains how women have become part of the history of dayah education in Aceh, drawing attention to the differences between ascribed and achieved modes of power. In this section, I present the cases of two dayahs in Aceh, namely Dayah Darussalam and Dayah Mudi Mesra, to provide examples of women whose authority is 'ascribed' to them by virtue of their kinship ties to male dayah leaders. Social status, as Rosaldo and Lamphere (1974) have explained, can be ascribed or achieved and both modes can be important in explaining the social position of women. When power or social status is ascribed, this often happens through kinship relations and hereditary factors. This means that people assume a particular social status, political position, or leadership position through their (kinship) connections with a particular figure or leader. When social status or power is achieved, it is not so much kinship, but rather people's own struggles and efforts and achievements that serve to define their authority and position.

Acehnese dayahs have much in common with pesantrens and traditional institutions of Islamic learning elsewhere in the Indonesian archipelago (Dhofier 1982; Mastuhu 1994). However, there are also important differences between the dayahs in Aceh and analogous schools elsewhere in the region. In Java, large family networks between pesantrens emerged as a result of endogamous marriages among the ranks of the kiais (pesantren leaders) (see Dhofier 1982). In Aceh, such intensive networks of endogamous marriages are rare. This does not mean that the world of the dayahs is not also characterized by a form of hereditary authority. Rather, Acehnese people tend to think about the cross-generational transfer of dayah leadership in a different way. During my research, I found some women dayah leaders who originated from non-dayah families. This situation contrasts sharply with that of the pesantren nyais whom I observed during my earlier fieldwork in Java, particularly in East Java. All of the nyais whom I met there, and who have roles in the pesantren leadership, were from the immediate families of (male) pesantren kiais.

Two different terms are commonly used to refer to female dayah leaders in Aceh: teungku inong (female ulama) and inong teungku (wife of an ulama). Teungku inong are women who acquired their positions - and the power and authority associated with these positions — on their own, rather than through marriage with an ulama. Inong teungku, in contrast, is a term that is somewhat similar to the nyai in the Javanese context. However, while the term nyai can designate either the wives or daughters of a kiai (Marcoes 1992, 203-227), the Acehnese inong teungku refers only to the wives of the teungku. In Javanese pesantrens, the nyai is usually the kiai's representative for the women's section 
of the pesantren. When those nyais have higher knowledge of Islam, they will have even more authority and take over the leadership of (a part of) the pesantren. ${ }^{7}$ Comparing these nyais in Java with the inong teungkus in Aceh, then, one may say that the expectations of a nyai are generally higher than of an inong teungku. This is because, in Aceh, the inong teungku figure can be more easily separated from her husband's role as teungku. Some of my observations and interviews suggest that some teungku inongs even quit their own public religious roles, including their roles as religious teachers, once they become inong teungku (by marrying a teungku).

Women have been involved in dayah education in Aceh since at least the nineteenth century, as demonstrated by the life of Teungku Fakinah. Teungku Fakinah was married to Teungku Ahmad who then founded a dayah in Lam Krak, Aceh Besar, with the support of Teungku Fakinah's father. In 1873, Teungku Fakinah's husband died in battle against the Dutch, after which she took over his role in the armed struggle. She was reported to have some female students (Mardhiah Aly 1980).

In general, however, socio-cultural practices in Aceh have traditionally privileged men to study. This was partly due to the male tradition of meurantau ('leaving one's home area'), or jak u timo ('going to the East'), which means leaving one's village to study or work in another place (Siegel 1969, 54). To become an ulama, in other words, involved studying in dayahs that were far from home. In Javanese pesantrens this practice is called santri kelana while in Aceh it is known as meudagang, a term which originally means "to study," but also implies "to be a stranger, to travel from place to place" (Snouck Hurgronje 1906, 26). In the 196os, James Siegel wrote that "[t]he result of the meudagang is the transformation of ordinary villagers into ulama $[. .$.$] the$ pesantren student came back a different person" (Siegel 1969, 57). The term meudagang is still used for dayah students who leave their home or village to live in a dayah for the purpose of learning. ${ }^{8}$ Today, both boys and girls engage in meudagang. Some dayahs in Aceh now have a remarkably large number of female students. One example is Dayah Ulee Titi in Aceh Besar, where

7 One of the kiai's daughters in Jombang said that she had to leave her comfortable life in Jakarta when she decided to return home to take over the responsibility of developing the pesantren that she inherited from her parents after they died. Her brother formally took over the pesantren, but the presence of a nyai is needed for religious activities both in the pesantren and in the surrounding community.

8 The term meudagang is commonly used among (and for) students of traditional dayahs and rarely for students of modern dayahs or pesantrens such as Gontor 10 or Umar Diyan. 
the female students outnumber their male counterparts. The history of Dayah Mudi Mesra suggests that the dayah already had a few female students around 1927, when it was led by Teungku Haji Syihabuddin bin Idris, but today the number of female students comprises half of the total number of male students.

The emergence of modernist organizations and movements in other parts of the Indonesian archipelago, for example in Java and West Sumatra, went together with attempts to modernize the system of Islamic education. In the 1920s, modern Islamic schooling in the form of madrasahs was introduced in Aceh (Sulaiman 1988). This development caused contestation among the ulama, because traditionalist religious leaders resisted the idea of teaching secular or general subjects and the practice of teaching boys and girls simultaneously in the same space. A meeting which engaged community and religious leaders was held in Kuta Raja (Banda Aceh) on 2 October 1936. The consensus was that teaching general subjects and the co-education system are not forbidden from an Islamic point of view (Husein 1985), and both the inclusion of general subjects and the coeducational model of learning for girls and boys in the madrasah system continue until the present.

Today, most dayahs in Aceh have both male and female pupils, and separate dormitories for boys and girls. In some dayahs, boys and girls who are at the same educational level are taught simultaneously by their teacher in one pavilion (Ac. balee) (Baihaqi 1976). ${ }^{9}$ Over the past century, the number of female pupils studying in pesantrens or dayahs has increased. However, the number of women leaders of pesantrens or dayahs is still low, at less than ten per cent, at least according to official records, such as documents produced at the district and provincial level offices of the Ministry of Religious Affairs, or the Office for Dayah Education and Development (Badan Pendidikan dan Pengembangan Dayah).

This does not mean, however, that women are fully absent from dayah leadership, as we will see in the examples below. In Aceh, the teungku (sometimes also referred to as abon or waled) usually lives with his family in the dayah compound. His daily routine consists of teaching higher-level Islamic religious texts (kitab kuning) to senior pupils, who at the same time are also the instructors of younger pupils. If his wife is also a teungku, she may also teach the female pupils of the dayah. However, it is not always the case that a teungku's

9 Balee in this context is a semi-permanent place made of a wooden floor and it was traditionally the place for dayah students to learn. The compound of a dayah might have several balee, depending on the number of students studying in the dayah. 
wife has a dayah background. On the other hand, there are also some teungku inong who do not owe their position to kinship ties of being the wife or daughter of a teungku.

Examples of both types of female religious leadership in the world of Acehnese dayah will be explored here with references to examples from two well-known dayahs, namely Dayah Darussalam and Dayah Samalanga (which includes Mudi Mesra and Dayah Muslimat) in order to provide examples of female religious leaders whose authority is ascribed to them on account of their relations, by marriage or kinship, to male dayah teachers (Ac. teungku).

Dayah Darussalam, founded at Labuhan Haji (South Aceh) in 1936, was once an important center of (traditionalist) dayah education in Aceh. Its founder was Abuya Mudawaly, whose contribution to the dayah tradition in Aceh may be compared to that of Kyai H. Hasyim Asy'ary in Java, because the majority of other dayah leaders in the subsequent period were the students of Abuya Mudawaly, before they went on to found their own dayahs or become dayah leaders themselves (Waly 1993). One of Abuya Mudawaly's wives was Umi Rabiah, whose knowledge of Islam was well-respected and acknowledged by the community. I first came to know about Umi Rabiah from the stories of one of Abuya Mudawaly's grandchildren, who referred to her as an ulama perempuan (female religious scholar). Several sources from Abuya Mudawaly's family mentioned that she used to say she would only marry a man who could defeat her in a debate on Islamic religious knowledge. As the story goes, only Abuya Mudawaly was able to surpass her knowledge and defeat her in a debate. After her divorce from Abuya Mudawaly, she went on to establish her own school, a dayah for girls in the village of Lam Pisang, near Dayah Darussalam.

The centrality of Dayah Darussalam at Labuhan Haji diminished considerably after the death of Abuya Mudawaly. The absence of a figure as strong as Abuya Mudawaly, in terms of religious authority and even political influence, was one of the reasons for this decline. The reconfiguration of dayah networks after his death was further driven by evolving socio-political dynamics of that time as Abuya Mudawaly and the traditionalist ulama that he represented came under increasingly pronounced public critique by Islamic modernists associated with PUSA. Over the latter decades of the twentieth century, however, there has been a considerable rapprochement between traditionalist and modernist ulama in Aceh with the spectrum shifting in the direction of modernizing reform.

Today, the heart of dayah education in Aceh has 'shifted' from Labuhan Haji, on the west coast, to Samalanga, on the north coast. One of the leaders of Dayah Mudi Mesra at Samalanga was Teungku Abdul Aziz, a former student of Abuya Mudawaly. He was married to a daughter of Teungku Hanafiah Abbas, the 
leader of Dayah Mudi Mesra from 1935-1964. When Teungku Hanafiah Abbas passed away in 1964, Teungku Abdul Aziz took over the leadership of the dayah. At that time the majority of the students were boys, although this would later change. Since 1989, the majority of students there have been girls. Teungku Abdul Aziz's brother-in-law, Teungku Jalaluddin Hanafiah, managed the girls' part of the dayah compound, which is called Dayah Muslimat. In this, he was assisted by his wife, Umi Ainiyah. While there were separate compounds for boys and girls, the dayah under Teungku Abdul Aziz's leadership also had a few female students. When Teungku Abdul Aziz and his wife, Umi Fathimah, moved into the compound of the current Dayah Mudi Mesra, many female pupils followed the couple and stayed with them there.

Over time, the number of female pupils grew steadily, and villagers established dormitories for them. It was Teungku Abdul Aziz's wife, Umi Fathimah, who initially developed the complex of the dayah for girls. She used to be called mi nek (grandma) by her pupils. One of her students, who is now an instructor for female pupils in Dayah Mudi Mesra, told me that she was an active woman who "just couldn't sit quietly." In her time, there were no male teungkus who taught female pupils; all female pupils were taught by women, and she was strict about maintaining this principle. After managing the women's section of Dayah Mudi Mesra for some years after her husband's death, Umi Fathimah made the pilgrimage to Mecca. Before she left, she handed over the leadership of the girls' section to her son-in-law, Waled Hasanoel Bashry (aka Waled Hasanon).

Waled Hasanon was a student of Teungku Abdul Aziz, and he later married his teacher's daughter and became his successor. Under their leadership, the dayah grew and developed further, with thousands of male and female students from all over Aceh going there to study. Today, it is the largest dayah in Aceh, in terms of student numbers, facilities, teachers and alumni networks. This growth was also accompanied by other changes to the dayah. Whereas in Umi Fathimah's time the female pupils were taught only by female instructors, under Waled Hasanon's leadership male instructors also teach in the female students' pavilion (balee), with a curtain separating the teacher from his female pupils.

The part of Dayah Mudi Mesra that initially was a dayah only for girls was named Dayah Muslimat. Teungku Abdul Aziz's brother-in-law and his wife, Umi Ainiyah, inherited and managed this part of the dayah. One of Umi Ainiyah's students told me that she used to teach some classes and sometimes also taught the students how to weave mats. In one of my discussions with her, I found that she was able to quote from memory passages from the kitab kuning, that is, the texts of the Islamic religious sciences that she had taught at Dayah 
Mudi Mesra. One of her daughters married Waled Nuruzahri (Waled Nu), who then founded another dayah close to Dayah Muslimat, called Ummul Aiman. Waled Nuruzahri's wife is called 'Bunda' (mother) by her dayah pupils. She is involved in managing the dayah and she also teaches this dayah's pupils.

Apart from their responsibilities in regular dayah instruction, some teungku inong are also active in social and religious activities in the community outside their dayahs. Those teungku inong maintained a relationship with the local population, not only through a regular majelis taklim (study group) to study classical texts, but also through the practice of Sufi rituals, which bestow on them a particular form of religious authority. One of the former students of Dayah Mudi Mesra described Umi Ainiyah as being both a inong teungku and a teungku inong, and said: "Even in her eighties, she was strong enough to lead the rituals and recite the dhikr herself, sometimes almost without any sleep." Because of her great standing in the community, Umi Ainiyah was often invited to religious and cultural ceremonies. Sometimes her schedule could be quite full and, for example, after delivering a sermon in a majelis taklim, she might be invited immediately for another event. Even at her advanced age, she maintains a busy schedule of leading Sufi rituals during the month of Ramadan. The local community refers to her as a 'religious leader' in terms of her socio-religious activities and leadership in the dayah and within the local community. ${ }^{10}$

The examples discussed above explain how religious authority can be ascribed through ties of kinship. For women, this means that they assume authority mostly based on the positions of either their fathers or husbands, or bothas in the case of Umi Ainiyah's daughter, who also inherited religious authority from her mother. In other cases, however, women can assume religious authority even without the support of kinship ties to other Islamic teachers. Their authority is 'achieved' through their own accomplishments in the study of Islamic religious sciences and mastery of ritual practice. The claims to authority of the female ulama discussed below derive from their studies of classical Islamic texts, and thus their power could be thought of as achieved rather than ascribed. At the same time, however, their authority is also elaborated in terms of the broader social contexts in which they operate. As they assume diverse social roles in their community, however, their religious learning remains the primary defining feature of their status.

10 Once, for example, I observed a woman who came with her family to see Umi Ainiyah to ask her and her congregation to pray for her late mother. Since Umi Ainiyah was away, the woman asked her daughter, who was also a teungku inong, and the daughter agreed to do it. 


\section{Teungku Fatimah Cut}

Teungku Fatimah Cut was born on 28 December 1929 into a family without direct connections to the world of the dayah. From 1936 to 1940, she attended a Dutch colonial primary school. When she was fifteen years old, she started to study under the guidance of the charismatic modernist ulama leader, Abu Daud Beureuh. From 1941 to 1945, she received dayah education at Pesantren Darul Huda Bambi in the region of Pidie. In 1945, she married Teungku Hasan Is. She later continued her education at one of the dayahs in Lampoh Saka, Pidie, from 1966 to 1967. Teungku Fatimah Cut established her dayah in 1978, with herself as Director and her husband as Secretary. This is remarkable as I did not find this kind of relationship in my research on pesantren leadership anywhere in Java, where a nyai never occupies a position of authority higher than that of her husband. The highest position a nyai can assume is that of joint leader of the pesantren together with her husband. Since the death of her husband, Teungku Fatimah Cut's daughter has assisted her in managing the dayah. Together they have developed vocational training programs, including the production of local batik (although, eventually, this activity ceased due to the armed conflict that prevented them from obtaining the cloth from Java).

Although at the time it was still rare for women to pursue university education, after her dayah education in the late 196os, Teungku Fatimah Cut went on to attend both the IAIN Ar-Raniry and the Akademi Dakwah in Jakarta, obtaining the degree of Bachelor of Arts (sarjana muda). According to Teungku Fatimah Cut, when she established her own dayah in 1978, it was Daud Bereueuh himself who gave it the name of Fathimiyah, referring both to a Muslim dynasty of medieval Egypt, and to her own name: Fatimah. Before Teungku Fatimah Cut established the dayah, she was already a well-known orator and preacher, who used to accompany Daud Beureueh while he was preaching (mendakwah). Over the course of her career, she became engaged with the modernist ideas of the time, and with PUSA, the organization led by Daud Beureueh. She incorporated modernist ideas into the syllabus at the dayah by teaching not only religious subjects, but also general subjects and vocational skills-while distancing herself from Sufi ritual practice and tarekat. At the same time she actively engaged in dakwah (proselytization) on tours all across Aceh.

Apart from engaging in religious activities, Teungku Fatimah Cut was also active in the struggle for independence. During the resistance against the Dutch after the Second World War, she became skilled in the use of weapons. Later, in 1967, she joined the Batalyon 113 in Kuta Bakti and eventually obtained the rank of corporal in the Muslimat army, or Muslim women defence 
force. ${ }^{11}$ It is unclear to me whether this was the first time that Teungku Fatimah Cut was involved in state-driven activities. Nevertheless, her ensuing career clearly shows her close attachment to political activities and to state agencies and government officials. In the 1970s she embarked on a political career, as she occupied a seat in the district parliament for two periods, from 1971-1977 and from 1977-1982, for Partai Persatuan Pembangunan (Unity Development Party, PPP).

Teungku Fatimah Cut also engaged in business activities. She was a contractor, who managed several infrastructure projects in Aceh, and she was a member of the association of contractor organizations. This work was also recognized by the Indonesian government, and she was nominated to receive the 'Satya Lencana Award,' honouring significant achievements in the field of development under the Suharto administration. Through her connections at the national level she attracted support for her dayah from several foundations, including the Suharto family's Yayasan Darmais. Her abilities to obtain such funds for Islamic education under the New Order testify to her extensive connections to national elites, built through her experience in politics.

As a female preacher who travels around Aceh, Teungku Fatimah Cut is still a well-respected, articulate orator speaking fluently in Arabic, Japanese, and English as well as in Acehnese and Indonesian. Most recently, she completed a translation of the Qur'an into the Acehnese language.

\section{Teungku Zahrul Husna (Umi Husna)}

Teungku Zahrul Husna was born in September 1966 in Jangka Buya, Ulhe Glee, in the district of Pidie. She began her formal education studying Islamic religious sciences in a dayah nearby in her village. ${ }^{12}$ After completing her elementary education in 1981, she continued her studies at Dayah Mudi Mesra in Samalanga. Teungku Abdul Aziz (Abon Aziz) was still alive at that time and so she had the opportunity to study directly under him. Teungku Abdul Aziz always selected the best of his students to be taught exclusively in one special class comprised of male and female students. During these lessons, men and women were separated by a curtain. ${ }^{13}$ This special class had two class managers

11 Women's groups received military training and, where necessary, were also involved in combat.

12 The Dayah Babul Macarif, led by Teungku Haji Munir.

13 The students of this remarkable class included: Teungku Hanan (one of Abu Seulimeum's sons); Teungku Bulqaini Tunjungan, the leader of Dayah al-Aziziyah in Lueng Bata; and Teungku Faisal Ali, the leader of Dayah Mahyal Ulum al-Aziziyah Sibreh, who was elected 
(ketua kelas): Teungku Faisal Ali for male students and Umi Husna for female students. While Umi Husna went on to found her own dayah, other female students in that group took up other kinds of religious leadership roles by establishing balee seumeubeut, and have thus also come to be recognized as teungku inongs by their community.

In 1994, Umi Husna, as one of the advanced students in the dayah, was instructed by Waled Hasanon to further her studies of Sufism under Abu Wahab at Seulimum. ${ }^{14}$ She went there with some other selected students and they were accompanied by the wife of Teungku Abdul Aziz. Thereafter, she participated in the activities of the Naqshbandiyya Sufi order (I. tarekat) and eventually received a certificate (ijaza) indicating her initiation into that order. She then became a Sufi master herself and served to lead particular Sufi practices (suluk and kaleut) of the Naqshbandiyya in her community. ${ }^{15}$ Like Umi Husna, Tengku Abdul Azis's daughter in law, Umi Ainiyah, has also been known as someone who leads Sufi rituals, particularly during Ramadan.

Umi Husna was married to Teungku Kamal, a student of Abu Syam Marpali of Dayah Babul Huda. The marriage was arranged by the two dayah leaders of Dayah Babul Huda and Dayah Mudi Mesra. After they got married, the couple settled in Blang Pidie, where they rented a small shop selling copies of the Qur'an, kitab kuning, and Muslim clothing. While her husband was finishing his education with Abu Syam of Dayah Babul Huda, Umi Husna started to teach children from surrounding areas, particularly Qur'an recitation. In 2000, they established a dayah to which they moved their activities. They called the

as the leader of Nahdlatul Ulama for the province of Aceh. All of the alumni who established their own dayah have al-Aziziyah's name applied to their dayah. Therefore, the dayah of Umi Husna and her husband was named Dayah Darul Kamal al-Aziziyah, and the dayah of Teungku Faisal Ali in Sibreh, Aceh Besar, is called Dayah Mahyal Ulum alAziziyah. Being the largest traditional dayah in Aceh today, Dayah Mudi Mesra has an extensive network in, and even beyond, Aceh. The haul (annual) meetings to commemorate the late Abon Aziz are attended by thousands of participants, including local and national government officials.

14 Someone who has been initiated into a Sufi order (tarekat) receives an ijaza (certificate), and s/he will have a right to lead the tarekat rituals, or become a tarekat leader.

15 Suluk is a type of retreat for Sufi practitioners who congregate with their shaykh for an intensive ritual regime of devotions and religious instruction. Kaleut (from the Arabic for 'seclusion') is a form of ritual retreat emphasizing the 'remembrance' (Ar. dhikr/I. zikir) of God, in which participants cover their faces with cloth so that they cannot see anything and cannot be seen by others. They do not talk but rather practice zikir. Both kaleut and suluk participants wear white clothes and cover their faces with a white cloth or a white-coloured mukena for women. 
dayah Darul Kamal al-Aziziyah. In the local community, the presence of this new dayah has been met with enthusiasm and many local children now study there. The dayah has about 500 male and female students; some of them reside in the dayah compound (santri mukim), while others (santri kalong) return to their homes after the classes because they live nearby.

This dayah also has a class for adults through its majelis taklim activities. The majelis taklim for men used to be held every Friday afternoon after prayer and was managed by Umi Husna's husband Teungku Kamal until his death in 2001. The women have two meetings each week; one on Thursday afternoon for studies of Islamic jurisprudence ( figh), ritual practice (ibadat) and religious ethics (akhlaq), and one on Friday morning for the recitation of the 36th chapter of the Quran (wirid Ya Sin). Umi Husna manages and leads all of these activities herself. This dayah also has a special class for the most talented students of the dayah, similar to Dayah Mudi Mesra Samalanga. It was Umi Husna, and not her husband who was responsible for teaching this special class. After her husband's death, Umi Husna managed and directed the dayah on her own, being a leader for both female and male students.

Umi Husna then also took over the management of the majelis taklim for men, in addition to the majelis taklim for women. It is very uncommon for women to give majelis taklim for an exclusively male congregation. Almost everywhere in Aceh (and across the Muslim world, for that matter), women are usually instructors only for groups of other women (Frisk 2009). At first, Umi Husna tried to find other male teungkus to replace her, but after the participants complained she resumed the position of instructor for the men's majelis taklim herself. Although Umi Husna admits that it can sometimes be uncomfortable for her, as a woman, to talk with her male participants about such sensitive issues as reproduction, bodily hygiene, and sexual relationships, she maintains that she feels obligated to explain things clearly and directly. As she put it: "After I have explained something, I will ask them whether they have understood it and say 'if you want to laugh you can laugh later, but what is important now is that you have understood this." 16

As someone who has been formally initiated into the Naqshbandiyya Sufi order with a license (ijaza) to teach it to others, Umi Husna is also allowed to lead the suluk ritual in her dayah. The story of Umi Husna and other women like her demonstrates the extent to which some Acehnese women can attain considerable authority through their own studies of texts and ritual training. Dur-

16 "Leuh lon syarah lon tanyong, peu ka muphom. Menyoe keunek khem ta khem enteuk, yang penteng muphom dile." Interview on 3 September, 2011 at Aceh Barat Daya. 
ing my earlier research in East Java, I also met with women in leading positions, such as Nyai Adlan, who inherited the leadership of a tarekat from her husband Kiai Adlan at the Pesantren Putri Cukir of Diwek Jombang (Srimulyani 2012, 53). However, Umi Husna's husband was not a Sufi leader, and her father was a military officer who had no ulama background. In contrast, then, to the women who have their leadership status ascribed to them, Umi Husna achieved her legitimacy and authority as a religious leader entirely on her own.

To preserve their autonomy, some (female) religious leaders prefer to have no official relations with the state, even if that means not receiving any state subsidies for their dayah. This is the case for Umi Husna, who was offered financial assistance by the government, but refused the offer in order to preserve the independence of her school. She also rejected offers to join formal ulama organizations or activities, arguing that she prefers to focus all her time and energy on her dayah and the majelis taklim. Unlike Umi Husna's dayah, Umi Fatimah Cut's dayah has received subsidies from both the local and national governments. As noted above, Umi Fatimah Cut's political work has provided her with access to far better connections with the state apparatus. Sometimes government officials visit her in her dayah in Lampoh Saka. Although she sometimes participates in activities sponsored by ulama organizations, she is not a formal member of the Acehnese Ulama Council (MPU) at either the district or the provincial level. Thus, neither Umi Husna nor Umi Fatimah Cut, as well as the other teungku inong discussed in this chapter, have been directly involved in any of the official institutions of Aceh's state Shari'a system.

Nevertheless, a decade of formal state Shari'a implementation has also had some significant effects on Aceh's female ulama. For example, the size of their community congregation and the topics discussed during their religious lessons appears to have increased over recent years. Although there are no precise numbers available on this, it is clear that there is a growing interest among the people to attend religious events like the majelis taklim organized by these teungku inongs. This growth has been fostered, at least in part, by the efforts of the state to raise a greater awareness of the importance of the Shari'a through various official programs. ${ }^{17}$ Some majelis taklim are even officially endorsed by the government, such as the religious congregation for the high ranking officials set up by the current governor as well as the vice governor. The majelis taklim organized by these female ulama also engage with prominent aspects of Shari'a, as it is formally implemented in the province through discussions of high profile issues such as proper standards of Muslim dress, and the public 
role of women, among others. In doing this, however, the teungku inong generally prefer to speak from a position of scholarly independence, and continue to work outside the formal institutional structures of state Shari'a. Their distanced engagement with the official project for the state implementation of Islamic law further demonstrates the considerable agency that they can assert as religious authorities in their own right. As community religious leaders, they are consulted by the community on various matters, ranging from marital issues, family conflicts, inheritance, and even political affairs in the community, such as in the case of Islamic dress policies applied by the bupati (district head) of West Aceh district in 2010. ${ }^{18}$

In the post-tsunami/post-conflict period, some female religious leaders in Aceh have forged international connections, taking up the opportunities of a new cosmopolitanism through programs on gender and society conducted in the framework of the recovery of Aceh. Some teungku inongs have had the opportunity to join training and internship programs outside Aceh. This has included both Indonesian national programs, such as workshops on gender in the Islamic State University Syarif Hidayatullah in Jakarta, and an engagement with international initiatives and discourses that were introduced by international agencies and partner NGOS working in Aceh (see Afrianty 2015, and her contribution in this volume). Other teungku inong, however, have chosen not to engage with such networks. Many of them have other trans-local connections of their own, particularly in the form of Sufi orders, through which they engage with ideas and forms of ritual practice that expand their networks well beyond Aceh.

\section{Views on Gender Issues}

Aceh's long history of rule by female monarchs (Ar. sultana), as well as the prominence of female local chieftains and female heroines fighting against the Dutch all demonstrate that women in Aceh have for a long time assumed roles of public leadership (Reid 1988, 641). The Acehnese tradition of matrilocality may be one reason for the relatively high position of women (Siegel 1969). In Aceh, teungku inongs have played roles in the performance of Islamic religious

18 This policy, which was widely understood as prohibiting women from wearing trousers (I. celana panjang), invoked public debate both at the local level and at the provincial level through the local media. Among the religious figures consulted on this issue, both by the media and by the community through their religious congregations, were also teungku inongs, such as Umi Hanisah (see below). 
duties such as bathing the corpses of Muslim women, as well as in cultural (adat) ceremonies, such as the peusijeuk that is commonly performed during marriage ceremonies, birth celebrations, and funeral rites.

However, while teungku inongs are still invited to adat ceremonies, their role in these rituals appears to be no longer as dominant as it once was. Since the 1980s, majelis taklim have become more popular and important at both national and local levels. As in West Java, women in Aceh usually form the majority of majelis taklim participants (Millie 2011). Teungku inongs who possessed particular religious knowledge or expertise in religious teaching took the opportunity of the growing interest in majelis taklim to become instructors. The majority of the teungku inongs who became involved in this kind of religious congregations are graduates of dayahs. This is particularly true for the rural areas, whereas in urban areas some of the teungku inongs have received modern Islamic education, such as in a madrasah or PGA (Pendidikan Guru Agama-religious teacher education), or even higher Islamic learning such as at the Islamic State Institute (IAIN presently UIN) Ar-Raniry.

Against the background of the life stories and the roles of the female dayah leaders I have presented above, I turn now to explore the ways in which these female ulama perceive the position of other women within their communities, and what they think of the roles of women and gender relations in the household. Although public discourse on gender issues in Aceh has intensified during the post-tsunami/post-conflict period, most female dayah leaders have not participated very actively in these discussions. By contrast, many of their male counterparts from Aceh's dayah community regularly engage in the discussions, mostly by countering the concept of gender as they see it as a Western concept that is irrelevant for the Acehnese community. In general, however, public discourse on gender in contemporary Aceh is dominated by activists and ulama or experts with non-dayah educational backgrounds. But this does not mean that the teungku inongs do not have opinions on these issues. Let us therefore now take a closer look at the views of Teungku Fatimah Cut and Umi Husna.

Teungku Fatimah Cut is vocal in her criticism of some contemporary discourses on the role of women in Acehnese society. She does not agree with the restrictions that are placed on women in the name of Sharica:

Alah makooo ${ }^{19}$... according to Shari'a law, are women allowed to go to the market? And to the paddy field? [Are they allowed] to help their husbands 
in the paddy field? In the paddy field their aurat is uncovered. Do we want to be like women in Saudi Arabia? [...] here, we have to go to the paddy field, women carry sacks of rice on their heads, women mind the children, women trade in the market. Are those activities not [in line with] Sharia? [If someone tells you that women are not allowed to this and that], let me know and I will come to make it clear to her/him.

She also criticizes current patterns of gender relations in some sectors of Acehnese society:

See ... the men, and this is sometimes quite embarrassing, hang out in the coffee shops. They talk about America, but none of them feeds his family at home. I can say this, and I can prove this. Then, after finishing his coffee, upon leaving the coffee shop, such a man tells the owner to write it down [on his bill], as he has no money to pay for it now. How then can he possibly afford to support his family? [If everything is available and these men fully support their families], then they can tell their wives that they should just make themselves beautiful at home, sit down near the window without shopping tasks and without the responsibility for the livestock. Only if someone carries the rice for us, we can have perfume ... What do you think, do we agree with this as women? Do you think my ideas are bad?

Teungku Fatimah Cut is convinced that women should be independent and productive, saying: "You, women, are heroines. Do not give up seeking the truth and you will not be defeated; remember Khadija, remember Fatima, remember Aisha [wives and daughter or the Prophet Muhammad]." Teungku Fatimah Cut herself has always been productive and active, doing what she believed are good works (amal) for the betterment of the Muslim community (ummat), and she clearly does not want to be discriminated against for doing so. In her view, a Muslim woman should be strong and active and she should be allowed to pursue many professions. For this reason, she was astonished to hear of the case of a female sub-district head (camat) in Plimbang, Bireuen who was replaced by another district parliament member in 2010, simply because she was a woman and was therefore deemed to be unfit for such a leadership role by a few people including the head of the Bireuen district parliament, who brought the case to the public and received wider media attention.

Umi Husna has a somewhat different view, placing more emphasis on issues of modesty when discussing the mobility and activity of women in public 
space. According to her, as long as women wear proper dress and maintain their chastity, they can assume public positions in the state bureaucracy or in the community without a problem, particularly if there is no one else who could take on the position. Umi Husna has also, however, maintained that in principle, women should always cover their face unless they have to see others and deal with others in their work. In her dayah in Samalanga, female students are recommended to wear the full face veil (chador).$^{20}$ This influences her view on proper Muslim dress for women, although she herself does not cover her face.

\section{Teungku Hanisah}

I will now compare the two dayah leaders discussed above with another female dayah leader, namely Teungku Hanisah from West Aceh, who is also called Umi Hanisah. Umi Hanisah was born on 3 July 1968 in Peunia, West Aceh (Aceh Barat). She spent nine years studying in Dayah Darussalam in South Aceh (Aceh Selatan), a well-known traditionalist dayah in Aceh. After completing her dayah education in South Aceh she decided to pursue higher education in Meulaboh (West Aceh) where she obtained a bachelor's degree in Islamic education. She married a teungku, but later divorced because her husband did not support her public activities outside the household. ${ }^{21}$ Her dayah education has given her a wide range of knowledge on Islam and a good understanding of kitab kuning. She has established and is leading a dayah in Padang Mancang, Meulaboh, that currently has approximately two hundred students.

Apart from her educational and leadership roles, she is specifically concerned with assisting victims of domestic violence, most of whom are women. Sometimes her dayah functions as a shelter for these women. Once, the local

20 The majority of female dayah students in Aceh are not obliged to (and do not) wear a face veil. In this regard, Dayah Mudi Mesra Samalanga is quite exceptional. The practice started quite recently in the 1990s. Before that, the female students covered their head with traditional batik cloth (kain batik panjang). Now, the chador has become their uniform and forms the identity of the dayah female students, although upon the completion of their study, the majority of them do no wear the chador any longer. In the surrounding community, women also do not wear the veil, and were not persuaded to do so through the religious congregations teachings or sermons, even if the instructors were from Dayah Mudi Mesra. 
people misunderstood her activities and claimed that she protected an adulterer, after which she had to leave her dayah for a while to avoid angering the community further. ${ }^{22}$ Umi Hanisah won the Aceh Women Award 2010 for her active role in campaigning and providing assistance for abused women and children. This is indeed a very different way of using agency as a religious leader. This kind of work would generally be seen as under the purview of social workers, and it is not necessarily related to the religious activities attached to the agency and authority of teungku inongs. The role of female religious leaders in such activities suggests that the teungku inongs can now use their positions for different activities than would have been possible for the teungku inongs of earlier generations.

Umi Hanisah is also an active advocate of women's rights and is sometimes openly critical of positions taken by the local government. She was a candidate for Partai Aceh in the general legislative elections in 2009. The Partai Aceh won the local elections and gained a majority of seats in the provincial parliament, and even in a number of districts across Aceh. During the run-up to the 2012 elections for governor and district heads, I asked Umi Hanisah about her thoughts on gender and politics. She replied: "I will only vote for a woman. If there are no female candidates, I will not vote for any candidates. I have had enough of them [the current leaders] and of what they have been doing so far. I would like to see a change." The background to this statement was formed by a district-level law passed in her home district of Aceh Barat in 2010. The law, prominently endorsed by the District Head, Ramli Mansur, banned women from wearing trousers. Umi Hanisah agreed that Islam sets particular rules related to Muslim women's dress in the concept of covering one's aurat, but she disagreed with the prohibition on women wearing (a modest type of) trousers. Commenting on this issue, she said:

I wear trousers sometimes for practical reasons. [...] Acehnese women should not be separated from their trousers as it is also their traditional dress. [...] I cannot understand why they always focus on women's dress. [...] [I cannot understand] why they don't care about having a better plantation system to improve the economy, or about developing good cooperatives. ${ }^{23}$

\footnotetext{
22 Interview with Umi Hanisah on 10 February 2009 in Banda Aceh.
}

23 Interview with Umi Hanisah on 27 February 2011 in Meulaboh. 


\section{Tu Zainab}

Another female ulama of the same generation, Tu Zainab, presents yet another profile of religious authority. As a daughter of Umi Ainiyah and a grandchild of Abu Aziz Samalanga, she studied in a dayah before her marriage and now she spends most of her time in the dayah. ${ }^{24}$ She currently runs 14 majelis taklims with more than 800 participants in total. She holds at least two such sessions every day, in which she teaches from the kitab kuning on basic principles of worship (ibadat), mostly related to matters of fiqh (jurisprudence). Her husband has supported her in taking on this task. ${ }^{25}$

Tu Zainab says that the majority of problems about which the majelis taklims' participants (almost all of whom are women) consult her are family matters, such as family conflicts and divorce. She says: "I tell them: do not always think that your husband is wrong, but look at yourself first. Maybe you also have a problem ... we [sometimes] do not understand our roles [as wives], we always blame our husband ... [but] we are not always correct ..."26 Such comments are quite common in religious congregations or sermons, and can be made either by male or female teungkus. Moreover, this discourse on the role of women as wives has been embraced by the general public, not only in Aceh but also Indonesia, and it used to be strongly emphasized in the gender ideology of the state (Blackburn 2004; Robinson 2009; Suryakusuma 1996). However, when I discussed this issue further with Tu Zainab, she also expressed her concern about the ways in which some husbands restrict their wife's public activities, and she recognized that there was some injustice in the unequal relationships within the household.

The four examples above suggest a variety of opinions on the social position of women held by Aceh's female ulama. Teungku Fatimah Cut and Umi Hanisah hold some broadly similar views. Their background as women who are active outside the dayah seems to influence the way in which they think of the position and the mobility of women. Umi Husna and Tu Zainab, on the other

24 She is known as Tu Zainab and not as Teungku Zainab. She most likely has had this title since she was young and it is probably the title used for members of the family of the ulama dayah. During my research, I found several other men and women who had this title, for instance Tu Rukaiyah and Tu Bulqaini from Tunjungan, both of whom are also dayah leaders.

25 He himself is known as 'Abati' and apart from teaching in an Islamic secondary school, he also has the task of accompanying his wife to her majelis taklims.

26 Interview with Tu Zainab on 4 March 2011. 
hand, concentrate and focus on the dayah or majelis taklim. Umi Husna, for instance, avoids any activity outside her dayah.

As Kloos (2010) has argued, the fact that a female dayah leader is in favour of Sharica law does not automatically mean that she cannot also engage in attempts to advance the social position of women. Also, even though there has been some critique on the effectiveness of the religious congregation model of majelis taklim in terms of addressing women's interests or improving their position, Millie $\left(2011,15^{2}\right)$ argues that it does provide access to "possible modalities in which agency can be exercised." All of the female dayah leaders discussed above manage religious preaching activities (dakwah) or majelis taklim, with women forming the majority of their participants. This provides them not only with agency but also with considerable religious authority in the eyes of their participants. Some teungku inongs also exercise this agency and authority through their roles in Sufi rituals. None of these activities seem to be strongly affected by the current state Shari'a project, but they are strongly situated within the socio-religious patterns of community life in Aceh.

\section{Conclusion}

The discussion on teungku inong dayahs in Aceh presents examples of two ways in which women in Aceh can assume agency and authority as religious leaders. Firstly, a woman can be a leader through her kinship with a male leader, not only in the religious sphere as discussed above, but also in politics. This confirms a model of ascribed power that exists in many Muslim communities. Apart from this ascribed power, however, some women in Aceh are able to achieve a particular position of religious leadership through their own efforts. Authority based on achieved power can give these female religious leaders agency analogous to that based on ascribed or relational power. Importantly, some of these women are also able to exercise their authority beyond the religious context by addressing issues that are relevant to contemporary socio-political realities of life in Aceh. Some of the female religious leaders discussed here engage in politics or activism for human rights, against domestic violence, or other issues. This is a new and different way in which they deploy their authority, which had previously been generally understood as confined to discussions of religious issues. Nevertheless, some others choose not to get involved in politics or social activism. Still, they too have become influential in different ways through their networks of students and teachers affiliated with tarekat (Sufi orders) and their role in community rituals, as well as through their leadership in the dayah. 
Although there are relatively few female dayah leaders compared to their male counterparts in Aceh, their role is highly significant because they have an important influence on the social life of the community, particularly through informal public religious spaces. Even though their majelis taklim are sometimes limited to female participants, they have used these networks to establish and extend their authority in a wider community outside their dayahs. Therefore, even though most of them are not involved in the formal ulama organizations and institutions of state Shari'a, their work remains significant in the complex social dynamics of contemporary Aceh.

\section{References}

Afrianty, Dina. 2015. Women and Sharia Law in Northern Indonesia:Local Women's NGO s and the Reform of Islamic Law in Aceh. Abingdon and New York: Routledge.

Azra, Azyumardi. 2002. "Biografi Sosial-Intelektual Ulama Perempuan: Pemberdayaan Historiografi." In Ulama Perempuan Indonesia, edited by Jajat Burhannuddin, xxixxxviii. Jakarta: PT. Gramedia Pustaka Utama dan P PIM.

Baihaqi. 1976. Ulama dan Madrasah di Aceh. Jakarta: Lembaga Ilmu Pengetahuan Indonesia bekerja sama dengan Departemen Agama.

Blackburn, Susan. 2004. Women and the State in Modern Indonesia. Cambridge: Cambridge University Press.

Burhanudin, Jajat, ed. 2002. Ulama Perempuan Indonesia. Jakarta: Gramedia Pustaka Utama.

Dhofier, Zamakhsyari. 1982. Tradisi Pesantren: Studi Tentang Pandangan Hidup Kiyai. Jakarta: Lembaga Penelitian, Pendidikan dan Penerangan Ekonomi dan Sosial.

Formichi, Chiara, 2012. Islam and The Making of the Nation: Kartosuwiryo and Political Islam in Twentieth-century Indonesia. Leiden: KITLV.

Frisk, Sylva. 2009. Submitting to God: Women and Islam in Urban Malaysia. NIAs Press: Denmark.

Husein, Ibrahim. 1985. Persepsi Kalangan Dayah terhadap Pendidikan Tinggi di Aceh. Paper presented at a seminar at IAIN Ar-Raniry, 21-23 February 1985.

Kloos, David. 2010. "Supporting Syariah, Advancing Women." Inside Indonesia, Juli-Sept 2010. http://www.insideindonesia.org/weekly-articles-101-jul-sep-2010/supporting -syariah-advancing-women-31071904.

Marcoes, Lies. 1992. "The Female Preacher as a Mediator in Religion: A Case Study in Jakarta and West Java." In Women and Mediation in Indonesia, edited by S. van Bemmelen et al., 203-227. Leiden: KIT Lv Press.

Mardhiah Aly, Ainal. 1980. "Pergerakan Wanita di Aceh Masa Lampau Sampai Kini." In Bunga Rampai tentang Aceh, edited by Ismail Suny. Jakarta: Penerbit Bhratara Karya Aksara. 
Mastuhu. 1994. Dinamika Sistem Pendidikan Pesantren: Suatu Kajian tentang Unsur dan Nilai Sistem Pendidikan Pesantren. Jakarta: INIs.

Millie, Julian. 2011. "Islamic Preaching and Women Spectatorship in West Java." The Australian Journal of Anthropology 22:151-169.

Reid, Anthony. 1988. "Female Roles in Pre-Colonial Southeast Asia." Modern Asian Studies 22(3), Special Issue: Asian Studies in Honour of Professor Charles Boxer:629-645.

Robinson, Kathryn. 2002. "Gender Orders in Some Societies of the Indonesian Archipelago." Kultur (The Indonesian Journal for Muslim Culture) 2(2):1-20.

Rosaldo, Michelle Z., and Louise Lamphere, eds. 1974. Women, Culture, and Society. Stanford: Stanford University Press.

Siegel, James T. 1969. The Rope of God. Berkeley and Los Angeles: University of California Press.

Snouck Hurgronje, C. 1906. The Achehnese (2 Vols.). Leiden: E.J. Brill.

Srimulyani, Eka. 2008. "Negotiating Public Space: Three Nyais Generations in a Jombang Pesantren." In Indonesian Islam in New Era:How Women Negotiate Their Muslim Identities, edited by Susan Blackburn, Bianca Smith, and Siti Syamsiyatun, 119-138. Clayton: Monash University Press.

- 2009. "Women Leadership in Islamic Educational Institution in Java and Aceh." Kultur (The Indonesian Journal for Muslim Culture) 4(2):159-173.

- 2012. Women from Traditional Islamic Educational Institutions in Indonesia: Negotiating Public Spaces. Amsterdam: Amsterdam University Press.

Sulaiman, M. Isa. 1988. "Madrasah dan pembentukan elite modernis di Aceh." In Bunga rampai Temu Budaya Nusantara PKA-3, edited by Ismuha, 488-509. Banda Aceh: Seksi Seminar.

Suryakusuma, Julia. 1996. "The State and Sexuality in New Order Indonesia." In Fantasizing the Feminine in Indonesia, edited by Laurie J. Sears, 92-119. Durham: Duke University Press.

Waly, Muhibbuddin. 1993. Ayah Kami: Maulana Hají Muhammad Waly al-Khalidy. Singapore: Jew Printers \& Binders Pte. Ltd. 